\title{
PENERAPAN METODE MIND MAPPING PADA PEMBELAJARAN MATEMATIKA SIWA SMPN 48 SURABAYA
}

\author{
Aulia Nurdamayanti \\ SMP Negeri 48 Surabaya \\ nurd_aulia@gmail.com
}

\begin{abstract}
This research is based on the frequent learning of mathematics which is generally centered on the teacher, which is often considered able to make the students can understand the material given. While, students should participate actively in learning, to be able to build ideas through the ability and thought in accordance with their understanding. This research is quantitative descriptive. The techniques used in this study are observation, questionnaires, and tests. Learning model in this research is using mind mapping method, because mind mapping method can help students to not always record writing as a whole. Students can present words, ideas, made on their own thoughts, understanding and creativity, and can understand the material for a longer period of time. Based on the background, the purpose of this research is to describe the student activity during the application of mind mapping method, to describe the student's response and the learning result after applying the mind mapping method on persamaan garis lurus. The conclusion that can be drawn from the application of mind mapping method on the equation of persamaan garis lurus of students of class VIII SMP Negeri 48 Surabaya is that with mind mapping method can make the students more active role in the class. And for learning outcomes also experience mastery at equation of equation..
\end{abstract}

Keywords: mind mapping, activity, response, learning outcomes

\section{PENDAHULUAN}

Pendidikan memiliki peran penting dalam mempersiapkan sumber daya manusia yang berkualitas, yang mampu menghadapi tantangan dan siap berkompetisi dalam perkembangan ilmu pengetahuan dan teknologi. Pendidikan juga tidak lepas dari adanya peran seorang guru sebagai aktor ataupun fasilitator yang dapat memberikan pengetahuan bagi siswa. Guru sebagai fasilitator perlu melakukan pemilihan pengalaman belajar agar siswa dapat mengikuti pembelajaran secara baik dan maksimal. Berdasarkan UU RI Tahun 2003 Bab I pasal (1) perndidikan adalah usaha sadar dan terencana untuk mewujudkan suasana belajar dan proses pembelajaran agar siswa secara aktif mengembangkan potensi dirinya untuk memiliki ketentuan spiritual keagamaan, pengendalian diri, kepribadian, kecerdasan, akhlak mulia, serta pengendalian yang diperlukan dirinya, masyarakat, bangsa dan negara.
Dalam pendidikan dewasa ini, siswa dituntut dapat lebih mempersiapkan diri dalam segi

pemahaman dan apresiasi terhadap suatu pelajaran khusunya matematika. Matematika dapat diartikan suatu ilmu yang memiliki peran penting khususnya dalam kehidupan manusia sehari - hari. (Hasan, Alwi, \& dkk, 2002) Matematika secara umum ditegaskan sebagai penelitian pola dari struktur, perubahan, dan ruang; tak lebih resmi, seorang mungkin mengatakan adalah penelitian bilangan dan angka. Dalam pandangan formalis, matematika adalah pemeriksaan aksioma yang menegaskan struktur abstrak menggunakan logika simbolik dan notasi matematika; pandangan lain tergambar dalam filosofi matematika. Maka matematika penting untuk diberikan dan dipelajari oleh setiap individu manusia, baik sejak pendidikan sekolah dasar maupun sampai ke tingkat perguruan tinggi. Dalam pembelajaran matematika di sekolah, salah satu kompetensi lulusan yang diharapkan menurut Permendiknas No. 54 
Tahun 2013 adalah agar siswa memiliki kemampuan faktual, konseptual, dan prosedural, memiliki kemampuan pikir dan tindak yang efektif, kreatif dalam ranah abstrak maupun konkret sesuai yang dipelajari di sekolah serta sumber lain sejenis.

Seringnya pembelajaran matematika pada umumnya terpusat pada guru sebagai aktor. Siswa haruslah berperan secara aktif dalam proses pembelajaran, lebih mampu membangun gagasan serta ide hingga menemukan konsep matematika melalui kemampuan dan pemikiran sesuai dengan pemahaman mereka, serta memahami materi dalam jangka waktu yang lama. Pemikiran inilah yang menjadi dasar peneliti untuk memaksimalkan pelaksanaan proses pembelajaran melalui penerapan alternatif metode pembelajaran dengan memaksimalkan aktivitas, respon, dan hasil belajar siswa agar dapat memahami konsep materi yang disampaikan lebih baik. Aktivitas belajar dapat terwujud apabila siswa terlibat belajar secara aktif. (Yamin, 2007) mendefinisikan belajar aktif sebagai usaha manusia untuk membangun/pengetahuan dalam dirinya. Pembelajaran akan menghasilkan suatu perubahan dan peningkatan kemampuan, pengetahuan dan ketrampilan pada diri siswa. Siswa mampu menggali kemampuannya dengan rasa ingin tahunya sehingga interaksi yang terjadi akan menjadi pengalaman dan keinginan untuk mengetahui sesuatu yang baru. Respon dikatakan Darly Beum sebagai tingkah laku balas atau sikap yang menjadi tingkah laku adekuat. Sementara itu Scheerer menyebutkan respons merupakan proses pengorganisasian rangsang dimana rangsang-rangsang prosikmal di organisasikan. Sedemikian rupa sehingga sering terjadi representasi fenomenal dari rangsang prosikmal (Sarwono, 1998:32). (Dimyati \& Mudjiono, 2009:3) "hasil belajar adalah hasil dari suatu interaksi tindakan belajar dan tindakan mengajar". (Sudjana, 1999) menyatakan "hasil belajar adalah kemampuan - kemampuan yang dimiliki siswa setelah ia memiliki pengalaman belajarnya".

Atas dasar pemikiran tersebut, peneliti melakukan pembaharuan dalam pembelajaran matematika dengan pemilihan metode pembelajaran mind mappping atau peta konsep. Menurut (Mulyatiningsih, 2014) dan (Fitriatien, 2017) menyatakan bahwa mind mapping merupakan salah satu bentuk pembelajaran yang digunakan untuk melatih kemampuan menyajikan isi (content) materi pelajaran dengan pemetaan pikiran (mind mapping). Hasil dari mind mapping adalah mind map, dimana mind map adalah suatu diagram yang digunakan untuk mempresentasikan kata - kata, ide - ide, tugas - tugas ataupun suatu yang lainnya yang dikaitkan dan disusun mengelilingi kata kunci ide utama. Melalui metode pembelajaran mind mapping, siswa tidak lagi dituntut untuk selalu mencatat tulisan yang ada di papan tulis atau yang didiktekan oleh guru secara keseluruhan. Siswa akan mengetahui inti masalah, kemudian membuat peta pikirannya masingmasing sesuai dengan kreativitas mereka.

Strategi pembelajaran mind mapping dikembangkan sebagai metode efektif untuk mengembangkan gagasan - gagasan melalui rangkaian peta - peta. Salah satu penggagas metode ini adalah (Buzan, 2004). Untuk membuat mind map, menurut Buzan seoseorang biasanya memulainya dengan menulis gagasan utama ditengah halaman dan dari situlah ia bisa membentangkannya ke seluruh arah untuk menciptakan semacam diagram yang terdiri dari kata kunci - kata kunci, frasa - frasa, konsep - konsep, fakta - fakta, dan gambar - gambar (Huda, 2013). Pada hakekatnya, mind map digunakan untuk membrainstroming suatu topik sekaligus menjadi strategi ampuh bagi belajar siswa. 
Berdasarkan uraian diatas, peneliti melakukan penelitian dengan mengimplementasikan metode pembelajaran mind mapping, yang dengan penerapan metode ini dapat berdampak positif pada tujuan pembelajaran, yaitu aktivitas, respon, dan hasil belajar. Metode mind mapping ini diterapkan pada siswa kelas VIII SMP Negeri 48 Surabaya. Hal ini dilakukan dengan menerapkan metode mind mapping pada materi persamaan garis lurus. Adapun agar siswa mencapai hasil belajar yang baik dan dapat mecapai atau melampaui nilai Standar Ketuntasan Minimal yang diberikan oleh sekolah yaitu dengan nilai $\geq 70$.

Adapun permasalahan yang akan diteliti adalah: (1) Bagaimana aktivitas siswa selama penerapan metode mind mapping pada materi persamaan garis lurus?; (2) Bagaimana respon siswa setelah penerapan metode mind mapping pada materi persamaan garis lurus?; (3) Bagaimana hasil belajar siswa setelah penerapan metode mind mapping pada materi persamaan garis lurus?

Tujuan dari penelitian ini adalah: (1) Mendeskripsikan aktivitas siswa selama penerapan metode mind mapping berlangsung pada materi persamaan garis lurus; (2) Mendeskripsikan respon siswa setelah penerapan metode mind mapping pada materi persamaan garis lurus; (3) Mendeskripsikan hasil belajar siswa setelah penerapan metode mind mapping pada materi persamaan garis lurus.

\section{METODE PENELITIAN}

Dalam penelitian ini menggunakan pendekatan penelitian deskriptif kuantitatif yang merupakan penelitian yang bertujuan menjelaskan fenomenafenomena yang ada dengan menggunakan angkaangka yang kemudian dinarasikan untuk menjelaskan karakteristik individu atau kelompok.

Penelitian ini mengambil subjek penelitian satu kelas siswa kelas VIII SMP Negeri 48 Surabaya.
Dengan jumlah siswa sebanyak 37 orang, dengan 18 siswa laki - laki dan 19 siswa perempuan.

Teknik pengumpulan data yang digunakan dalam penelitian ini adalah observasi, angket respon, dan hasil belajr. Teknik observasi ini digunakan untuk mengamati aktivitas siswa selama pembelajaran dengan penerapan metode mind mapping, dan dilakukan oleh seorang pengamat. Pengamatan aktivitas siswa dilakukan pada 5 orang siswa dan dilakukan di setiap 5 menit. Angket respon digunakan untuk mengumpulkan data dari beberapa pernyataan yang diajukan terhadap pembelajaran dengan menggunakan metode mind mapping, yang diukur dari 2 indikator 'setuju' dan 'tidak setuju'. Tes evaluasi digunakan untuk mengetahui keterampilan dan pengetahuan yang dimiliki oleh siswa dengan tujuan untuk mengetahui pemahaman siswa terhadap pembelajaran yang telah dilalui dan untuk mengetahui hasil belajar siswa. Tes evaluasi ini diberikan setelah pembelajaran selesai, dan terdiri dari 5 soal uraian.

Analisis data yang digunakan adalah (1) analisis data aktivitas belajar siswa, data dari hasil pengamatan aktivitas siswa digunakan untuk mendeskripsikan aktivitas siswa selama proses pembelajaran dengan menerapkan metode mind mapping; (2) analisis data respon siswa, dari hasil pengamatan aktivitas siswa digunakan untuk mendeskripsikan respon siswa setelah proses pembelajaran dengan menerapkan metode pembelajaran mind mapping; (3) analisis hasil belajar, data hasil belajar siswa digunakan untuk mendeskripsikan hasil belajar siswa selama proses pembelajaran berlangsung dengan menerapkan metode mind mapping dan berpedoman pada tiga aspek, yaitu aspek kognitif, afektif, dan psikomotor. Berikut adalah rentang nilai untuk aspek afektif dan psikomotor. 
Tabel 1. Rentang Nilai Hasil Belajar

\begin{tabular}{cc}
\multicolumn{2}{c}{ RENTANG NILAI } \\
\hline Nilai & Predikat \\
\hline 0,00 skor $\leq 1,00$ & D \\
1,00 skor $\leq 1,33$ & D+ \\
1,34 skor $\leq 1,67$ & C- \\
1,68 skor $\leq 2,00$ & C
\end{tabular}

\section{HASIL PENELITIAN}

Penelitian tentang penerapan metode mind mapping ini dilaksanakan pada tanggal 24 Oktober 11 November 2017 di SMP Negeri 48 Surabaya pada materi persaman garis lurus. Penelitian ini dilaksanakan pada 3 kali pertemuan. Hasil penelitian yang didapat akan dijelaskan mengenai aktivitas siswa selama pembelajaran di dalam kelas, respon dan hasil belajar siswa dalam aspek kognitif, afektif, dan psikomotor dengan penerapan metode mind mapping.

Dari hasil pengamatan aktivitas siswa pada pertemuan pertama, memperoleh presentase tertinggi adalah pada kategori kedua, yaitu siswa memperhatikan penjelasan guru mengenai materi persamaan garis lurus dengan nilai presentase sebesar $31,25 \%$. Pada pertemuan kedua, memperoleh presentase tertinggi adalah pada kategori kedua, yaitu siswa memperhatikan penjelasan guru mengenai materi persamaan garis lurus dengan nilai presentase sebesar $28,75 \%$. Untuk pertemuan ketiga memperoleh presentase tertinggi adalah pada kategori keempat, yaitu siswa membuat catatan mind mapping dengan nilai presentase sebesar $32,5 \%$.

Hasil respon siswa dari pernyataan 1 sampai dengan 10 mendapatkan nilai untuk ungkapan 'setuju' sebesar $88,64 \%$ dan untuk ungkapan 'tidak setuju' mendapat presentase sebesar $11,36 \%$, dapat dilihat pada tabel dibawah ini :

$\begin{array}{lr}2,01 \text { skor } \leq 2,33 & \text { C+ } \\ 2,34 \text { skor } \leq 2,67 & \text { B- } \\ 2,68 \text { skor } \leq 3,00 & \text { B } \\ 3,01 \text { skor } \leq 3,33 & \text { B+ } \\ 3,34 \text { skor } \leq 3,67 & \text { A- } \\ \text { 3,68 skor } \leq 4,00 & \text { A }\end{array}$

Tabel 2. Hasil Respon Siswa

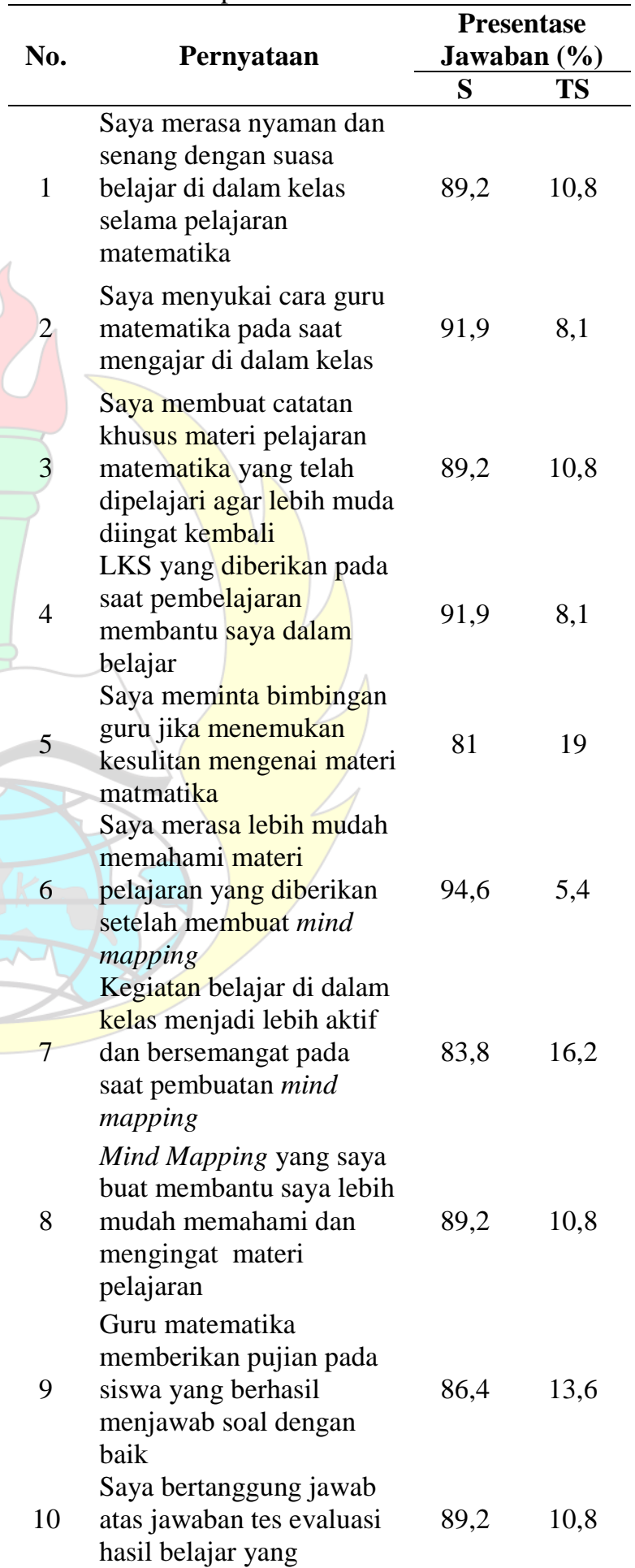




\begin{tabular}{|c|c|c|c|}
\hline \multirow[t]{2}{*}{ No. } & \multirow[t]{2}{*}{ Pernyataan } & \multicolumn{2}{|c|}{$\begin{array}{c}\text { Presentase } \\
\text { Jawaban }(\%)\end{array}$} \\
\hline & & $\mathbf{S}$ & TS \\
\hline \multicolumn{4}{|c|}{$\begin{array}{l}\text { diberikan oleh guru } \\
\text { setelah pembelajaran }\end{array}$} \\
\hline & Rata Presentase & 88,64 & 11,36 \\
\hline
\end{tabular}

Terlihat bahwa respon yang didapat adalah positif dengan ditunjukkannya hasil rata - rata 'setuju' yang lebih dominan, hal ini dikarenakan siswa lebih mudah memahami materi dengan menggunakan metode mind mapping.

Hasil belajar siswa dalam aspek kognitif, diperoleh siswa yang tuntas belajar pada materi persamaan garis lurus sebanyak 30 siswa dan siswa yang tidak tuntas ada sebanyak 7 orang siswa. Karena nilai Standar Ketuntasan Minimal yang harus dicapai siswa adalah $\geq 70$. Hasil belajar aspek afektif pada pertemuan pertama siswa yang dikataka tuntas sebanyak 20 siswa dan yang tidak tuntas sebanyak 17 siswa. Pada pertemuan kedua, siswa yang dikataka tuntas sebanyak 26 siswa dan yang tidak tuntas sebanyak 11 siswa. Dan pada pertemuan ketiga, siswa yang dikataka tuntas sebanyak 32 siswa dan yang tidak tuntas sebanyak 5 siswa. Dari hasil ketiga pertemuan itu didapatkan nilai rata - rata hasil belajar aspek afektif dari pertemuan pertama hingga ketiga dapat dilihat pda tabel dibawah ini :
Untuk hasil belajar aspek psikomotor pada pertemuan siswa yang tuntas sebanyak 24 siswa dan yang tidak tuntas sebanyak 13 siswa. Pada pertemuan kedua, siswa yang tuntas sebanyak 26 siswa dan yang tidak tuntas sebanyak 11 siswa. Dan pada pertemuan ketiga, siswa yang tuntas sebanyak 31 siswa dan yang tidak tuntas sebanyak 6 siswa. Dari hasil ketiga pertemuan tersebut, diperoleh nilai rata - rata seperti pada tabel dibawah ini :

Tabel 4. Rata - Rata Hasil Belajar Aspek Psikomotor

\begin{tabular}{clc}
\hline No & \multicolumn{1}{c}{ Kategori Penilaian } & \multicolumn{1}{c}{$\begin{array}{c}\text { Rata - } \\
\text { rata }\end{array}$} \\
\hline 1 & $\begin{array}{l}\text { Siswa membuat catatan mind } \\
\text { mapping dengan sungguh } \\
\text { sungguh }\end{array}$ & 3,06 \\
\hline 2 & $\begin{array}{l}\text { Catatan mind mapping yang } \\
\text { telah dibuat, dituangkan secara } \\
\text { terstruktur dan jelas }\end{array}$ & 3,13 \\
3 & $\begin{array}{l}\text { Hasil kerapian dan keberanran } \\
\text { siswa dakam pembuatan mind } \\
\text { mapping }\end{array}$ & 3,22 \\
\hline
\end{tabular}

Dari data tabel diatas, dapat dilihat bahwa untuk kategori penilaian pertama dari mulai pertemuan pertama hingga ketiga memperoleh hasil rata - rata sebesar 3,06. Untuk kategori penilaian kedua dari mulai pertemuan pertama hingga ketiga, nilai yang diperoleh sebesar 3,13. Dan untuk kategori penilaian ketiga mendapat nilai rata - rata sebesar 3,22.

\section{PEMBAHASAN}

Tabel 3. Rata - Rata Hasil Belajar Aspek Afektif

\begin{tabular}{clc}
\hline No. & \multicolumn{1}{c}{$\begin{array}{c}\text { Kategori } \\
\text { Penilaian }\end{array}$} & Rata - rata \\
\hline 1 & Keaktifan & 2,98 \\
2 & Tanggung Jawab & 3,09 \\
3 & Ketelitian & 3,19 \\
\hline
\end{tabular}

Terlihat untuk kategori penilaian keaktifan memperoleh hasil rata - rata sebesar 2,98. Untuk kategori penilaian tanggung jawab dari mulai pertemuan pertama hingga ketiga, nilai yang diperoleh sebesar 3,09. Dan untuk kategori penilaian ketelitian dari pertemuan pertama hingga ketiga mendapat nilai rata - rata sebesar 3,19.

\section{Aktivitas Siswa}

Pengamatan aktivitas siswa dilakukan pada 5 orang siswa dan diamati oleh seorang pengamat, dan pengamatan dilakukan setiap 5 menit dari jumlah 80 menit setiap pertemuan terhadap 8 kategori yang teramati. Untuk pertemuan pertama, bahwa pengamatan aktivitas siswa pada kedelapan kategori terlihat bahwa kategori yang memperoleh presentase tertinggi adalah pada kategori kedua, yaitu siswa memperhatikan penjelasan guru mengenai materi persamaan garis lurus dengan nilai presentase sebesar 
$31,25 \%$, dikarenakan siswa sangat antusias pada saat diminta untuk maju kedepan dan mempresentasikan hasil yang telah mereka peroleh. Pada pertemuan kedua, untuk kategori pertama presentase tertinggi masih sama pada kategori kedua dengan perolehan presentase sebesar 28,75\%, Pada pertemuan ketiga, untuk perolehan presentase tertinggi terlihat pada kategori keempat sebesar 32,5\%, Dapat disimpulkan dari data yang disampaikan diatas, bahwa siswa antusias dalam pembuatan mind mapping pada materi persamaan garis lurus karena pembelajaran menjadi lebih aktif, dan siswa lebih mudah memahami materi dengan catatan mind mapping yang dibuat oleh mereka sendiri.

\section{Respon Siswa}

Angket respon siswa diberikan setelah peneliti melakukan penelitian. Terdapat 10 pernyataan pada angket yang diberikan kepada/siswa mengenai kegiatan belajar mengajar dikelas dan metode mind mapping yang telah diterapkan sebelumnya. Hasil respon siswa dibagi dalam 2 indikator respon ungkapan 'setuju' dan 'tidak setuju'. Dari kedua indikator tersebut, dihasilkanl presentase ungkapan 'setuju' dan 'tidak setuju' dengan nilai rata - rata yang diperoleh untuk ungkapan 'setuju' mendapat presentase sebesar $88,64 \%$ dan ungkapan 'tidak setuju' dengan hasil presentase sebesar $11,36 \%$.

Terlihat bahwa respon yang terjadi selama pembelajaran dengan menerapkan metode mind mapping mendapat respon yang positif, dengan siswa merasa lebih mudah memahami materi dengan mind mapping, dan pembelajara di kelas menjadi lebih aktif. Hal ini dapat dilihat dari hasil rata - rata presentase ungkapan 'setuju' mendapat nilai yang cukup tinggi.

\section{Hasil Belajar Siswa}

\section{a. Hasil Belajar Siswa Aspek Kognitif}

Pada penelitian aspek kognitif, dilakukan dengan pemberian tes evaluasi dengan 5 soal uraian. Siswa dikatakan tuntas apabila telah mencapai nilai Standar Ketuntasan Minimal yang telah ditentukan oleh pihak sekolah yaitu $\geq 70$. Siswa yang tuntas belajar pada materi persamaan garis lurus adalah sebanyak 30 siswa dan siswa yang tidak tuntas adalah 7 orang siswa.

Hal ini dapat disimpulan bahwa pembelajaran menggunakan metode mind mapping lebih mempermudah siswa dalam memahami materi yang disampaikan, sehingga pada saat dilakukannya tes evaluasi sebagian besar siswa mendapat nilai diatas standar ketentuan.

\section{b. Hasil Belajar Aspek Afektif}

Terdapat 3 kategori yang akan diamati, yaitu aktif, tanggung jawab, dan teliti. Ketiga aspek tersebut akan diamati pada masing - masing individu siswa dengan rentang dan indikator penilaian yang telah ditentukan, yaitu $1-4$. Siswa dikatakan tuntas apabila memperoleh nilai rata - rata $\geq 3,00$ dengan predikat baik.

Dari hasil pengamatan yang telah dilakukan dari pertemuan pertama hingga ketiga, dapat dihitung hasil rata - rata dari ketiga pertemuan tersebut. Pada pertemuan pertama untuk kategori keaktifan memperoleh nilai 2,86, pada pertemuan kedua memperoleh nilai 2,91. Sedangkan pada pertemuan ketiga memperoleh nilai 3,18. Hasil aspek keaktifan yang diperoleh mulai dari pertemuan pertama hingga pertemuan ketiga memperoleh nilai rata - rata sebesar 2,98. Dalam kategori tanggung jawab, pada pertemuan pertama memperoleh nilai 3,00, pada pertemuan kedua memperoleh nilai 3,08, pada pertemuan ketiga memperoleh nilai 3,21. Dan rata rata yang diperoleh adalah 3,09. Kategori ketelitian, pada pertemuan pertama memeperoleh nilai 3,05, 
pada pertemuan kedua memeperoleh niliai 3,21. Untuk pertemuan ketiga memperoleh nilai 3,32. Rata - rata yang diperoleh untuk kategori ketelitian adalah 3,19 .

Dapat disimpulkan bahwa hasil belajar siswa aspek afektif dari setiap pertemuan mengalami perubahan yang baik. Dari hasil ketuntasan siswa yang meningkat dari pertemuan - pertemuan sebelumnya, baik dalam kategori penilaian keaktifan, tanggung jawab, dan ketelitian.

\section{c. Hasil Belajar Siswa Aspek Psikomotor}

Terdapat 3 kategori yang akan diamati. Ketiga kategori tersebut diamati pada masing - masing individu siswa dengan rentang dan indikator penilaian yang telah ditentukan, yaitu denga rentang $1-4$. Siswa dikatakan tuntas apabila memperoleh nilai $\geq$ 3,00 dengan predikat $\mathrm{B}$.

Dari hasil penelitian, diperoleh nilai rata - rata untuk hasil belajar aspek psikomotor, pada kategori penilaian yang pertama memperoleh nilai 3,02, pada pertemuan kedua memperoleh nilai 3,08, dan pada pertemuan ketiga memperoleh nilai 3,10. Dan menghasilkan nilai rata - rata sebesar 3,06. Pada kategori penilaian yang kedua, memperoleh nilai 3,08, pada pertemuan kedua memeperoleh nilai 3,13, dan pada pertemuan ketiga memperoleh nilai 3,18 , menghasilkan rata - rata sebesar 3,13. Pada kategori penilaian yang ketiga, yaitu kerapian dan kebenaran siswa dalam membuat mind mapping pada pertemuan pertama memperoleh nilai sebesar 3,13, pada pertemuan kedua memperoleh nilai 3,24, kemudian pertemuan ketiga memperoleh 3,29. Dan menghasilkan rata - rata sebesar 3,22.

Dari hasil nilai rata - rata yang telah diuraikan diatas, dapat disimpulkan bahwa hasil belajar siswa aspek psikomotor mengalami perubahan yang baik dari setiap pertemuan. Terlihat dari adanya peningkatan yang terjadi pada setiap kategori penilaian yang terjadi pada setiap pertemuan. Dapat dikatakan bahwa metode mind mapping yang telah dibuat siswa mengalami perkembangan yang baik.

\section{SIMPULAN DAN SARAN}

\section{Simpulan}

Dari penerapan metode mind mapping pada materi persamaan garis lurus siswa kelas VIII SMP Negeri 48 Surabaya dapat diambil kesimpulan sebagai berikut : Pertama, aktivitas siswa yang dominan pada pertemuan pertama terletak pada kategori kedua, dengan presentase sebesar 31,25\%. Pada pertemuan kedua juga terjadi pada kategori kedua dengan presentase sebesar 28,75\%. Sedangkan pada pertemuan ketiga, aktivitas siswa yang dominan terjadi pada kategori keempat dengan presentase $32,5 \%$. Hal ini terjadi menunjukkan bahwa siswa memusatkan perhatian pada saat guru menjelaskan materi, dan antusias dalam menuntaskan pembuatan mind mapping pada materi persamaan garis lurus.

Kedua, respon siswa memperoleh hasil yang positif dengan ditunjukkannya hasil rata - rata dengan ungkapan 'setuju' memperoleh hasil presentase sebesar $88,64 \%$. Ini terlihat bahwa siswa dapat memhami materi lebih mudah dengan menggunakan metode mind mapping.

Ketiga, tes hasil belajar siswa setelah mengikuti pembelajaran dengan penerapan metode mind mapping, pada aspek kognitif, untuk siswa yang tuntas sebanyak 30 orang, dan 7 orang siswa tidak tuntas. Untuk aspek afektif, hasil belajar siswa dari setiap pertemuan mengalami perubahan yang baik. Dari hasil nilai rata - rata ketuntasan siswa mulai pertemuan pertama sampai ketiga, baik dalam kategori penilaian keaktifan dengan nilai 2,98, tanggung jawab dengan nilai 3,09 dan ketelitian dengan nilai 3,19. Dan pada aspek psikomotor, untuk kategori penilaian pertama dari mulai pertemuan pertama hingga ketiga memperoleh hasil rata - rata 
sebesar 3,06. Untuk kategori penilaian kedua dari mulai pertemuan pertama hingga ketiga, nilai yang diperoleh sebesar 3,13. Dan untuk kategori penilaian ketiga mendapat nilai rata - rata sebesar 3,22. Dapat disimpulkan, bahwa pembelajaran dengan menerapkan metode mind mapping dapat berdampak positif terhadap aktivitas, respon, dan hasil belajar siswa.

\section{Saran}

Saran yang dapat disampaikan dari penelitian ini adalah metode mind mapping dapat diberikan kepada siswa sebagai pengalaman baru dalam pembelajaran, dimana siswa dapat berperan aktif selama pembelajaran berlangsung. Dapat direkomendasikan atau sebagai tambahan referensi bagi guru dalam pembelajaran di dalam kelas, karena siswa dapat membuat catatan dari kata - kata, ide - ide berdasarkan pemikiran dan pemahaman mereka sendiri sehinggan lebih mempermudah siswa dalam memahami materi yang disampaikan dan dapat diingat dalam jangka waktu lama. Serta guru dapat melibatkan siswa secara lebih aktif dalam pembelajaran yang berlangsung di dalam kelas. Serta sebagai tambahan khasanah kepustakaan bagi guru di dari sekolah lain.

\section{DAFTAR PUSTAKA}

Buzan, T. (2004). Mind Mapp Untuk Meningkatkan Kreativitas. Jakarta: PT. Gramedia Pustaka Utama.

Dimyati, \& Mudjiono. (2009). Belajar dan Pembelajaran. Jakarta: Rineka Cipta.

Fitriatien, S.R., (2017), Penerapan Strategi Pembelajaran Mind Mapping pada Mata Kuliah Metode Statistika dalam Seminar Nasional Pendidikan Matematika 2017, Universitas PGRI Adi Buana Surabaya: Surabaya (hal. 899-902).

Hasan, Alwi, \& dkk. (2002). Kamus Besar Bahasa Indonesia. Jakarta: Balai Pustaka.

Huda, M. (2013). Model - Model Pengajaran dan Pembelajaran. Yogyakarta: Pustaka Pelajar.

Mulyatiningsih, E. (2014). Metode Penelitian Terapan Bidang Pendidikan. Bandung: Alfabeta. Sarwono. (1998). Teori - teori Psikologi Sosial. Jakarta: PT. Raja Grafindo Persada.

Sudjana, N. (1999). Dasar - Dasar Proses Belajar Mengajar. Bandung: Sinar.

Yamin, M. (2007). Profesionalisai Guru dan Implementasi KTSP. Jakarta: Gaung. 